\title{
Hubungan Pola Asuh Otoritatif, Kontrol Diri, Ketrampilan Komunikasi dengan, Agresivitas Siswa
}

\author{
Relationship Parenting Authoritative, Self-Control, Communication Skills with, Aggressiveness \\ on Student \\ Dr. AM Diponegoro \\ Muhammad Abdul Malik \\ Magister Psikologi UAD
}

\begin{abstract}
Abstrak
Penelitian ini bertujuan untuk mengetahui hubungan pola asuh otoriatif, kontrol difi, ketrampilan komunikasi dengan agresivitas secara terpisah. Metode pengumpulan data dalam penelitian ini adalah dengan menggunakan skala Agresivitas, skala Pola asuh Otoritatif, skala Kontrol difi, dan Skala Ketrampilan Komunikasi yang disusun sendiri. Model skala yang digunakan adalah skala Liken. Dalam penelitian ini populasinya adalah siswa SMA kelas X, yang berjumlah 7 kelas dengan jumlah keseluruhan 229 siswa dengan rumus slovien Pengambilan sampel dalam penelitian ini berjumlah 70 siswa dari 229 siswa yang ada, sehingga diharapkan sampel yang ditetapkan sudah representatif. Hasil penelitian menyebutkan variabel yang memberikan kontribusi terbesar adalah variabel Ketrampilan Komunikasi (X3) yaitu sebesar 13,44\%, kemudian Pola Asuh (X1) dengan kontribusi 10,11\% dan variabel Kontrol Din ( X2) memilki kontribusi 3,92\%. Hasil analisis pertama memperoleh nilai $\mathrm{F}=7,211, \mathrm{p}=0,000(\mathrm{p}<$ $0,05)$, dan $R^{2}=0,213$. Hal ini menunjukkan bahwa terdapat korelasi antara pola asuh otoritatif (X1), kontrol diri (X2), dan ketrampilan komunikasi (X3) secara bersamasama terhadap agresivitas (Y).
\end{abstract}

Kata Kunci : Pola Asuh, Kontrol Diri, Komunikasi, Agresifitas

\begin{abstract}
This study aims to determine the relationship of authoritarian parenting, Difi control, communication skills with aggressiveness separately. Data collection method in this research is to use the aggressiveness scale, scale Authoritative parenting style, scale Difi Control and Communication Skills Scale were compiled. Model scale used is the scale Liken. In this study population were high school students of class $X$, which amounted to 7 classes with a total of 229 students with slovien formula samples in this study were 70 students out of 229 students there, so expect the sample set is representative. The results mentioned variables that provide the greatest contribution is variable Communication Skills (X3) that is equal to 13.44\%, and Parenting (X1) with a contribution of $10.11 \%$ and a variable control Din (X2) have the contribution of $3.92 \%$. The results of the first analysis to obtain the value of $F=7.211, p=0.000(p<0.05)$, and $R 2=0.213$. This indicates that there is a correlation between authoritative parenting style (X1), self-control (X2), and communication skills (X3) jointly against aggressiveness $(Y)$.
\end{abstract}

Keywords: Parenting, Self-Control, Communications, aggressiveness 


\section{Pendahuluan}

Agresivitas di kalangan remaja menjadi perhatian banyak kalangan baik dalam masyarakat maupun di dunia pendidikan. Perilaku kekerasan ini memberikan citra potret buram bagi dunia pendidikan. Aksi-aksi kekerasan yang sering dilakukan remaja sebenarnya adalah perilaku agresi dari diri individu atau kelompok. Agresi sendiri menurut Myer (2012) mendefinisikan agresivitas sebagai perilaku fisik atau yang bertujuan untuk menyakiti orang atau menyebabkan kerusakan padabenda.

Dan sebuah jajak pendapat Kompas bulan Oktober 2012, dengan responden di 12 kota di Indonesia, diketahui sebanyak 17,5\% responden mengakui bahwa saat dibangku SMA, sekolahnya pernah terlibat tawuran antar pelajar. Tidak sedikit pula responden atau keluarga responden yang mengakui pada masa bersekolah terlibat tawuran atau perkelahian masaal antar pelajar, jumlahnya mencapai 6,6 \% atau sekitar 29 responden. Di antara pelajar laki-laki, tawuran seperti sudah menjadi tradisi yang hams dilakukan. Kalau tidak ikut tawuran, tidak jantan, tidak keren, tidak mengikuti perkembangan zaman, atau banyak lagi anggapan lain.

Di SMA Negeri 4 Yogyakarta juga terjadi pemukulan teman dalam satu kelas, hanya gara-gara tidak mau membelikan es campur. Catatan lain dan gum Bimbingan dan Konseling, beberapa siswa SMA Negeri 4 Yogyakarta mengejar dan memukuli siswa sekolah lain karena dianggap berteriak dengan cara tidak sopan di lingkungan SMA Negeri 4 Yogyakarta (Catatan BK, 2013).

Menurut Rogers (2004) agresi verbal dapat bersifat terbuka (terhadap anak lain atau objek tak bernyawa) atau tertutup pada diri sendiri sebagai suatu wicara mandiri yang maladaptif. Anak yang agresif selalu memiliki kecenderungan untuk menguasai segala keadaan.

Pola asuh orang tua memberikan warna dalam konsep diri seorang individu, Perlakuan yang diberikan oleh orangtua pada masa kecil seorang individu akan memberikan pengalaman yang membentuk konsep din individu dalam mensikapi lingkungannya. Keluarga memiliki fungsi tidak hanya terbatas pada penerus keturunan raja namun juga sebagai fungsi pendidikan. Anak merupakan bagian dari keluarga yang secara sosial dan psikologis tidak terlepas dan pembinaan dan pendidikan orang tua, masyarakat dan lembaga pendidikan. Pembinaan dan pendidikan terhadap Individu tergambar dalam pola asuh orang tua. Oleh sebab itu, orang tua hams menyadari bahwa pola asuh sangat berpengaruh terhadap konsep diri seorang individu.

Kontrol diri yang baik sangat diperlukan remaja untuk mengendalikan emosi dalam mengatur perilakunya agar tidak berperilaku agresif. Kontrol diri merupakan kemampuan individu untuk mengendalikan emosi, dorongan-dorongan dari dalam dirinya untuk mengatur proses-proses fisik, psikologis, perilaku dalam menyusun, membimbing, mengatur dan mengarahkan bentuk perilaku yang positif agar dapat diterima dalam lingkungan sosial (Feist, 2008 ).

Ketrampilan komunikasi mutlak dibutuhkan dalam melakukan interaksi dengan lingkungan sekitar, kemampuan untuk menyampaikan dan menerima pesan harus dikuasai agar proses hubungan sosial dapat berjalan dengan baik. Bila pesan tidak 
diterima dengan benar maka akan berakibat konflik dalam proses interaksi.

Menurut Elksnin dan Elkisnin (dalam Hertinjung, 2006) ketrampilan komunikasi yaitu salah satu ketrampilan yang diperlukan untuk menjalin hubungan sosial baik. Kemampuan komunikasi ini tentunya dapat dilihat dari beberapa bentuk yaitu mendengar responsif, mempertahankan perhatian dalam pembicaraan dan memberikan umpan balik terhadap lawan bicara. Menurut Elksnin dan Elkisni (Hertinjung, 2006) ketrampilan komunikasi merupakan salah satu ciri-ciri ketrampilan sosial.

Kemampuan mendengar secara responsif adalah kemampuan untuk dapat merespon setiap pesan yang diberikan orang lain secara proporsional sesuai dengan pesan yang disampaikan. Pemilihan kata yang tepat dalam berkomunikasi tentunya akan menciptakan suasana yang nyaman dalam melakukan proses iteraksi sosial.

\section{Studi Literatur}

Myer (2012) mendefmisikan agresivitas sebagai perilaku fisik atau verbal yang bertujuan untuk menyakiti orang atau menyebabkan kerusakan pada benda. Hal senada juga diungkapkan oleh oleh Baron (2003) mengemukakan agresi adalah tingkah laku yang diarahkan kepada tujuan menyakiti makhluk hidup lain yang ingin menghindari perlakuan semacam itu. Definisi dari Baron ini mencakup empat faktor tingkah laku, yaitu: tujuan untuk melukai atau mencelakakan, individu yang menjadi pelaku, individu yang menjadi korban, dan ketidak inginan si korban menerima tingkah laku si pelaku, Baron menambahkan bahwa perilaku agresif dapat dilakukan secara fisik maupun mental. Dengan demikian dapat dilihat dan diamati, karena memiliki bentuk yang jelas, yaitu bentuk fisik (pukulan, tendangan), dan verbal (cacian, hujatan, makian).

Agresif dapat didefinisikan juga sebagai suatu tindakan yang memiliki maksud dan tujuan untuk melukai orang atau objek lain dan hal itu dilakukan dengan kesengajaan (Sears, dkk, 2000, h.4). Seorang ahli mengatakan bahwa agresivitas bukan sekedar agresif yang berbentuk fisik yang bermanifestasi dengan cara menendang, memukul, atau menghajar saja, tetapi ada kriteriakriteria tertentu yang dipakai untuk

memahami dan mengerti bahwa sesuatu itu merupakan agresivitas atau bukan(Mappiere, 2002, h.88).

Bentuk-bentuk agresivitas yang diarahkan keluar maupun ke dalam merupakan gejala umum tingkah laku agresif, hal ini dapat diarahkan keluar maupun ke dalam diri seseorang seperti bertindak kasar sehingga menyakiti orang lain, berkelahi, membuat onar di sekolah, mengolokolok secara berlebihan, mengabaikan perintah dan melanggar peraturan.

Agresivitas juga melibatkan setiap bentuk penyiksaan psikologis atau emosional seperti mempermalukan, menakut-nakuti atau mengancam (Breskwell dikutip Berkowitz, 2003). Penjelasan mengenai agresi banyak dikemukakan oleh banyak ahli psikologi. Namun pada dasarnya mereka memiliki kesamaan pendapat bahwa agresif adalah tingkah laku seseorang untuk menyerang, menyakiti, dan melukai orang lain atau objek secara fisik maupun psikis. Suatu unsur penting dari agresi yang harus ada yaitu adanya tujuan atau kesengajaan dalam melakukannya.

Dan berbagai teori yang ada dapat disimpulkan bahwa agresivitas adalah perilaku fisik atau verbal yang 
bertujuan untuk menyakiti orang atau menyebabkan kerusakan pada benda.

Sikap agresif secara internal dipengaruhi oleh beberapa faktor. Pertama kepribadian, kepribadian seorang individu dibentuk oleh lingkungan dengan belajar sosial sehingga konsep diri, kontrol diri dan regulasi diri sangat banyak dipengaruhi oleh lingkungan individu tumbuh dan berkembang. Kemampuan individu mengontrol diri sendiri dipengaruhi oleh budaya dilingkungan. Markus \& Nurius (Calhoun \& Acoceila dalam Irawan, 2013) juga merinci aspek-aspek diri pada lima aspek, yaitu: (1) aspek dirifisik (aspek tubuh yang di dalamnya berlangsung berbagai aktivitas biologis), (2) aspek diri-sebagaiproses (berupa: akal, emosi, dan perilaku), (3) aspek diri-sosial (potensi untuk berinteraksi dengan orang lain), (4) aspek konsep-diri, dan (5) cita-diri (apa yang diharapkan/diinginkan).

Kedua hubungan interpersonal, hubungan interpersonal mencakup ketrampilan berkomunikasi, seorang individu yang memiliki ketrampilan komunikasi yang kurang baik akan memicu agresivitas dalam hubungan dengan orang lain, sebaliknya bila memiliki ketrampilan komunikasi yang baik maka akan mengakibatkan agresivitas yang rendah.

Ketiga frustasi adalah kondisi dimana individu tidak dapat mencapai keinginan atau gagal mencapai tujuan yang diinginkan atau mengalami hambatan dalam kebebasan bertindak. Menurut Dollar Miller (Sarwono 1996) agresi dipicu oleh frustasi merupakan pelampiasan perasaan frustasi

Menurut

Schneiders (Widyaningrum 1998) rasa bersalah dan agresi sangat berhubungan karena rasa bersalah merangsang kebutuhan hukuman. Individu berperilaku agresif untuk mendapatkan hukuman dengan hukuman tersebut dapat mengurangi rasa bersalah dalam dirinya.

Keempat, usia dan jenis kelamin, dijelaskan oleh Hessel (Hurlock,1996) remaja usia 14 tahun memasuki masa perubahan yang rawan dan mudah marah sering tidak memperhatikan norma dan mudah melakukan perilaku agresif. Menurut American Psychology Association (Sarwono 1996) Adanya hormon testoteron pada laki-laki mengakibatkan laki-laki lebih Secara eksternal agresiftas dipengaruhi oleh faktor-faktor

Kelima, deindividuasi, mengurangi atau menyingkirkan peranan beberapa aspek dalam individu yakni identitas dan personalitas. Deindividuasi memiliki peran besar keleluasan individu dalam melakukan agresi.

Keenam, pola asuh (Interaksi parental) Cole (dalam Widyaningrum 1998) penolakan orangtua terhadap anak akan nampak dalam sikap bermusuhan, tidak memberikan kasihsayang, mengkritik dan mencela akan mengakibatkan periaku agresif dalam diri anak. Menurut Baumrind (dalam Santrock, 2007: 167) terdapat empat tipe pola asuh yaitu pola asuh otoritarian, pola asuh otoritatif, permisif yang mengabaikan dan Permisif yang menuruti. Darr tipe pola asuh menurut Baumrind diatas pola asuh orang tua yang otoritatif (demokratis) merupakan pola asuh yang paling tepat, karena dalam pola asuh otoritatif orang tua mendorong anak untuk mandiri namun masih menerapkan batas dan kendali pada tindakan anak.

Ketujuh, interaksi teman sebaya, menurut Lee (dalam Wungu, 1998) remaja yang tumbuh dalam yang agresivitas maka individu tumbuh menjadi agresif, agar individu dapat diterima oleh lingkungannya. 
Alkohol dan obat-obatan, menurut Phill dan Ross (dalam Brigham, 1991) alkohol dalam dosis tinggi akan meningkatkan kemungkinan respon agresif. Pengaruh obat dalam taraf ketergantungan akan sering terlibat dalam tindakan kriminalitas yang menggunakan kekeresan untuk dapat memenuhi kebutuhan dana untuk membeli obat terlarang.

Kedelapan, suhu udara, menurut Sarwono (1996) suhu udara mempunyai pengaruh terhadap tingkah laku, Pada suhu udara yang tinggi akan mengakibatkan orang menjadi gelisah dan mudah marah maka mempunyai peluang yang besar untuk melakukan tindakan agresif.

Faktor lain Baron dkk (dalam Baron dan Byrne, 1984) mengatakan bahwa faktor lingkungan memberikan pengaruh terhadap perilaku agresif seperti, suhu udara, kesesakan, kebisingan, polusi udara, ion negatif udara. Faktor yang menimbulkan agresivitas adalah pola asuh orang tua, Orang tua memiliki kewajiban untuk menyiapkan anaknya dalam menghadapi kehidupan yang akan dilaluinya tentunya dengan mendidik, memberikan contoh, dan mengarahkan tingkahlaku agar dapat sesuai dengan norma yang diharapakan oleh orangtua. Interaksi secara terus menerus dalam membantu anak dalam menyiapkan perilaku yang sesuai dengan harapan orangtua membutuhkan proses yang baik. Pola asuh orangtua merupakan pola interaksi antara orangtua dan anak yang dapat mempengaruhi pembentukan kepribadian, tujuan pengasuhan ini adalah anak diajarkan untuk mampu bersosialisasi dengan mengajarkan anak bagaimana menjadi bagaian sebuah masyarakat (Andayani \& Koenjoro, 2004)

Pola asuh akan mempengaruhi proses pembentukan kemandirian emosional remaja karena kelwirga sebagai lingkungan yang paling dekat yang mempengaruhinya dalam kehidupan sehari-hari. Steinberg (dalam Sari, 2008) mendefinisikan pola kepengasuhan orangtua merupakan sekumpulan sikap orangtua terhadap anak yang diekpresikan melalui cara berkomunikasi dan menciptakan suasana emosional.

Menurut Baumrind (dalam Santrock 1998) pola asuh otoritatif adalah cara orang tua mendorong anak untuk mandiri namun tetap meletakan batasan dan kendali atas anak. Interaksi verbal sangat dibutuhkan dalam sebagai upaya menunjukkan kehangatan dalam dan persahabatan dalam mengasuh anak. Orangtua biasa melakukan proses pendekatan verbal kepada anak untuk memberikan kehangatan dan keakraban hubungan. Komunikasi akrab diciptakan untuk mengembangkan suasana kebersamaan yang tidak memberikan batas namun dalan suasana yang bertanggungjawab. Anak-anak yang tumbuh dalam pola asuh otoritatif cenderung lebih mampu bertanggungjawab dan mampu melakukan proses sosialisasi dengan lingkungan

Dariyo (2004) mengemukakan bahwa pola asuh otoritatif anak dan orangtua memiliki kedudukan sejajar. Suatu kegiatan dilakukan dengan secara bersama-sama merencanakan kegiatan dan membuat keputusan dengan mempertimbangkan kedua belah pihak yang berperan untuk mensukseskan kegiatan tersebut. Anak diberikan kebebasan dalam mengambil keputusan secara bertaggung jawab walau tentunya dalam kendali orang tua agar anak tidak mengambil keputusan secara sembrono tanpa memiliki 
pertimbangan yang akurat. Akibat pola asuh ini anak akan tumbuh sebagai individu yang bertanggung jawab terhadap tindakan yang dilakukan.

Dan pengertian para ahli, peneliti membuat kesimpulan bahwa pola asuh otoritatif adalah pola asuh yang memberikan pola hubungan yang hangat, mandiri dan bebas dalam mengambil setiap keputusan dengan memberikan batasan yang jelas, dan bertanggung jawab artinya apa yang dilakukan hams dapat dipertanggunjawabkan kepada orang tua.

Faktor yang lain yang mengakibatkan agresivitas adalah kontrol diri Rodin (dalam Widiana dkk, 2004) mengungkapkan bahwa kontrol diri adalah perasaan seseorang dapat membuat keputusan dan mengambi tindakan yang efektif untuk menghasilkan akibat yang diinginkan dan menghindari akibat yang tidak diinginkan. Goldfried \& Merbaum (dalam Ghufron dan Risnawita 2010) mendefmisikan kontrol diri sebagai suatu kemampuan untuk menyusun, membimbing, mengatur, dan mengarahkan bentuk perilaku yang dapat membawa individu kearah konsekwensi positif.

Messina dan Messina (dalam Gunarsa, 2009) menyatakan bahwa kontrol diri adalah seperangkat tingkah laku yang berfokus pada keberhasilan mengubah diri pribadi, perasaan mampu pada diri sendiri. Kebebasan untuk menentukan arah tujuan sesuai dengan keinginan dan kemampuan diri dan kemampuan untuk memisahkan antara perasaan dan pikiran rasional serta seperngkat tingkah laku yang berfokus kepada diri sendiri.

Hurlock (2000) menyatakan kontrol diri berkaitan dengan bagaimana indivdu mengendalikan emosi serta doronga-dorongan dalam dirinya menw-ut Gillion (dalam Gunarsa 2009) menyatakan bahwa kontrol diri adalah kemampuan individu yang terdiri tiga aspek yaitu kemampuan mengendalikan atau memahami tingkah laku yang bersifat menyakiti atau merugikan orang lain, Kemampuan bekerjasama dengan oranglaindan kemampuan untuk mengikuti peraturan yang berlaku serta kemampuan untuk mengungkapkan keinginan atau perasaan kepada orang lain tanpa menyakiti atau menyinggung perasaan orang lain tersebut.

Berdasarkan definisi-definisi yang ada maka peneliti menyimpulkan bahwa kontrol diri adalah kemampuan rmenyusun, membimbing, mengatur dan mengarahkan perilaku yang membawa kearah positif agar dapat mengambil keputusan dan tindakan yang efektif untuk mendapatkan akibat yang diinginkan tanpa menyinggung perasaan orang lain.

Hubungan interpersonal didalamnya ada ketrampilan komunikasi Santrock (2007) menyatakan bahwa ketrampilan komunikasi adalah ketrampilan yang diperlukan dalam berbicara, mendengar, mengatasi hambatan komunikasi verbal, memahami komunikasi non verbal dan mampu memecahkan konflik secara konstruktif Eggen (dalam Liliweri 1997) berpendapat bahwa ketrampilan komunikasi adalah kemampuan anak dalam menggunakan pengetahuannya dalam teknik komunikasi verbal, non verbal, dan melalu media komunikasi secara efektif untuk mempertahankan keaktifan dalam bertanya, kolaborasi dan interaksi murid yang sifatnya mendukung di dalam kelas.

Menurut Elkisnin dan Elkisnin (dalam Hertinjung, 2006) ketrampilan 
komunikasi yaitu suatu ketrampilan yang diperlukan untuk menjalin hubungan sosial yang baik. Kemampuan komunikasi ini tentunya dapat dilihat dalam beberapa bentuk antara lain: menjadi pendengar yang responsif, mempertahankan perhatian dalam pembicaraan dan memberikan umpan balik terhadap lawan bicara.

Berdasarkan definisi yang ada dapat disimpulkan bahwa ketrampilan komunikasi adalah Kemampuan untuk berbicara, mendengar secara responsif, mempertahankan perhatian dalam pembicaraan, memberikan umpan balik terhadap lawan bicara dan mengatasi mendengar secara responsif, mempertahankan perhatian dalam pembicaraan, memberikan umpan balik terhadap lawan bicara dan mengatasi hambatan komunikasi verbal dan kemampuan memahami komunikasi non verbal

\section{Metode Penelitian}

Dalam penelitian ini populasinya adalah siswa SMA N 4 Yogyakarta kelas $\mathrm{X}$, yang berjumlah 7 kelas dengan jumlah keseluruhan 229 siswa dengan rumus slovien Pengambilan sampel dalam penelitian ini berjumlah 70 siswa dari 229 siswa yang ada, sehingga diharapkan sampel yang ditetapkan sudah representatif.

Metode pengumpulan data dalam penelitian ini adalah dengan menggunakan skala Agresivitas, skala Pola asuh Otoritatif, skala Kontrol diri , dan Skala Ketrampilan Komunikasi yang disusun sendiri. Model skala yang digunakan adalah skala Likert, dengan empat alternatif.

Skala pola asuh otoritatif dan kontrol diri menggunakan jawaban (STS) sangat tidak sesuai, (TS) Tidak sesuai, (S) Sesuai, (SS) sangat sesuai.
Pada aitem favorable, jawaban sangat sesuai (STS) diberi skor 4, Sesuai (S) diberi skor 3, Tidak sesuai (TS) diberi skor 2, dan Sangat tidak sesuai (STS) diberi skor 1. Sementara pada jawaban Unfavorable STS diberi skor 4, Tidak sesuai (TS) diberi skor 3, Sesuai (S) diberi skor 2, dan Sangat sesuai (SS) dibei skor I.

Skala Agresivitas dan ketrampilan komunikasi menggunakan jawaban (S) Sering, (K) Kadang-kadang, (J) Jarang, (TP) Tidak Pernah. Pada aitem favorable (S) Sering diberi skor 4, ((K) Kadangkadang diberi skor 3, (J) Jarang diberi skor 2, (TP) Tidak Pernah diberi skor 1. Sementara untuk jawaban unfavorable (S) Sering diberi skor 1, ((K) Kadang-kadang diberi skor 2, (J) Jarang diberi skor 3, (TP) Tidak Pernah diberi skor 4 dan sebaliknya semakin tinggi skor yang diperoleh subyek mengindikasikan tingginya Pola asuh Otoritatif, Kontrol difi, dan Ketrampilan Komunikasi

\section{Hasil Dan Pembahasan}

Penelitian menggunakan teknik analisis regresi ganda dengan menggunakan uji asumsi terlebih dahulu.

\section{Uji Asumsi Normalitas}

Uji normalitas untuk mengetahui apakah gejala yang diselidiki yaitu pola asuh otoritatif, Kontrol diri, Ketrampilan Komunikasi, dan Agresivitas penyebarannya berdistribusi normal atau tidak. Uji normalitas dalam penelitian ini dilakukan dengan menggunakan uji one sample Kolmogorov-Smirnov Test. Normalitas data akan terpenuhi jika probabilitas atau $\mathrm{p}>0,05$. Berdasarkan analisis didapatkan rangkuman hasil sebagai berikut : 
Tabel 14: Rangkuman hasil analisis uji Normalitas Sebaran

\begin{tabular}{|c|l|c|c|c|c|}
\hline No & \multicolumn{1}{|c|}{ Variabel } & N & P & Sig & Keterangan \\
\hline 1 & Pola Asuh Otoritatif & 70 & 0.467 & $\mathrm{P}>0,05$ & Normal \\
\hline 2 & Kontrol Difi & 70 & 0,183 & $\mathrm{P}>0,05$ & Normal \\
\hline 3 & Ketrampilan Komunikasi & 70 & 0.080 & $\mathrm{P}>0,05$ & Normal \\
\hline 4 & Agresivitas & 70 & 0.607 & $\mathrm{P}>0,05$ & Normal \\
\hline
\end{tabular}

Tabel di atas menunjukkan bahwa P-value yaitu Asymp. Sig. (2-tailed) pada masing-masing variabel $\mathrm{P}>0,05$. Berdasarkan hal tersebut maka dapat disimpulkan bahwa residual telah memenuhi asumsi distribusi normal.

\section{Uji Linieritas}

Uji linearitas bertujuan untuk mengetahui apakah dua variabel mempunyai hubungan yang linear atau tidak secara signifikan. Uji ini biasanya digunakan sebagai prasyarat dalam analisis korelasi atau regresi linear.Pengujian pada SPSS dengan menggunakan Test for Linearity dengan taraf signifikansi 0,05. Dua variabel dikatakan mempunyai hubungan yang linier bila signifikansi (Linearity) kurang dari 0,05.

Berdasarkan analisis didapatkan hasil sebagai berikut :

Tabel 15: Rangkuman hasil analisis Uji Linieritas hubungan

\begin{tabular}{|c|l|c|c|c|c|c|}
\hline No & \multicolumn{1}{|c|}{ Variabel } & N & Harga F & P & Sig & Keterangan \\
\hline 1 & Pola Asuh Otoritatif & 70 & 155,452 & 0,000 & $\mathrm{P}>0,05$ & Linier \\
\hline 2 & Kontrol Difi & 70 & 190,455 & 0,000 & $\mathrm{P}>0,05$ & Linier \\
\hline 3 & Ketrampilan Komunikasi & 70 & 31,719 & 0,000 & $\mathrm{P}>0,05$ & Linier \\
\hline
\end{tabular}

Berdasarkan tabel di atas dapat diketahui bahwa nilai signifikansi pada variabel Pola asuh otoritatf sebesar 0,000, Kontrol diri sebesar 0,000, dan Ketrampilan Komunikasi Linearity sebesar 0,000. Karena signifikansi dari masing-masing $\mathrm{P}<0,05$, maka linieritas terpenuhi.

\section{Uji Multikolinieritas}

Uji multikolinearitas digunakan untuk mengetahui ada atau tidaknya penyimpangan asumsi klasik multikolinearitas yaitu adanya hubungan linear antar variabel independen dalam model regresi. Prasyarat yang harus terpenuhi dalam model regresi adalah tidak adanya multikolinearitas. Ada beberapa metode pengujian yang bisa digunakan diantaranya yaitu dengan melihat nilai inflation factor (VIF) pada model regresi

Tabel 16 :Rangkuman hasil pengujian Multikolinieritas

\begin{tabular}{|l|l|c|c|l|c|c|}
\hline No & \multicolumn{1}{|c|}{ Variabel } & N & \multicolumn{2}{|c|}{ Tolerance VIF } & Sig & Keterangan \\
\hline 1 & Pola Asuh Otoritatif & 70 & 0.930 & 1.075 & VIF < 5 & Non Multikolinieritas \\
\hline 2 & Kontrol Din & 70 & 0.989 & 1.011 & VIF < 5 & Non Multikolinieritas \\
\hline 3 & $\begin{array}{l}\text { Ketrampilan } \\
\text { Komunikasi }\end{array}$ & 70 & 0.939 & 1.065 & VIF < 5 & Non Multikolinieritas \\
\hline
\end{tabular}

Dari tabel di atas dapat diketahui nilai variance inflation factor (VIF) dan tiga variabel yaitu
Pola Asuh Otoritatif antar variabel independent tidak terjadi persoalan multikolinearitas. 


\section{Uji Heterokedastisitas}

Heteroskedastisitas adalah suatu keadaan dimana masing -masing kesalahan (residual) mempunyai varian yang berlainan. Heteroskedastisitas diuji dengan menggunakan uji koefisien korelasi Rank Spearman yaitu sebesar 1,075, Kontrol Diri sebesar1,011, dan Ketrampilan Komunikasi sebesar 1,065 yang menunjukkan lebih kecil dan 5, sehingga bisa diduga bahwa mengkorelasikan antara absolut residual hasil regresi dengan semua variable bebas. Bila signifikansi hasil korelasi lebih besar dari $0,05(5 \%)$ berarti non heteroskedastisitas atau homoskedastisitas. Hasil uji heteroskedastisitas ditunjukkan pada tabel di bawah ini

Tabel 17 :Uji Heterokedastisitas

\begin{tabular}{|l|l|c|c|c|}
\hline No & \multicolumn{1}{|c|}{ Variabel } & N Abs res & \multicolumn{1}{c|}{ Sig } & \multicolumn{1}{c|}{ Keterangan } \\
\hline 1, & Pola Asuh Otoritatif & 700.226 & $\mathrm{P}>0,05$ & Non Heterokedastisitas \\
\hline 2. & Kontrol Diri & 700.746 & $\mathrm{P}>0,05$ & Non Heterokedastisitas \\
\hline 3 & $\begin{array}{l}\text { Ketrampilan } \\
\text { Komunikasi }\end{array}$ & 700,065 & $\mathrm{P}<0,05$ & Non Heterokedastisitas \\
\hline
\end{tabular}

Berdasarkan tabel di atas menunjukkan tidak terjadi masalah heterokedastisitas, melainkan non heterokedastisitas

(homoskedastisitas), pengaruh variabel independen (Xi,karena nilai signifikansi pada masingmasing variabel menunjukkan $\mathrm{p}>$ 0.05

\section{Analisis Determinasi (R2)}

Analisis determinasi dalam regresi linear berganda digunakan untuk mengetahui prosentase sumbangan $\mathrm{X} 2$, Xi) secara serentak terhadap variabel dependen (Y). Koefisien ini menunjukkan seberapa besar prosentase variasi variabel independen yang digunakan dalam model mampu menjelaskan variasi variabel dependen. Dari nilai Koefisien determinasi R2 (Adjusted $\mathrm{R}$ Square) diperoleh angka sebesar 0,213 atau (21\%). Hal ini menunjukkan bahwa prosentase sumbangan pengaruh variable independen Pola Asuh Otoritatif (X1), Kontrol Diri (X2), dan Ketrampilan Komunikasi (X3) terhadap variabel dependen Agresivitas (Y) sebesar 21\%. Pola
Asuh otoritatif Kontrol diri dan Ketrampilan Komunikasi mampu menjelaskan sebesar $21 \%$ terhadap Agresivitas . Sedangkan sisanya sebesar $79 \%$ dijelaskan oleh variabel lain yang tidak diteliti.

Persamaan regresi linier berganda yang diperoleh dan perhitungan SPSS maka di dapatkan model persamaan regresi linier berganda sebagai berikut :

$$
\mathrm{Y}=9,364+0,252 \mathrm{Xl}+-0,235
$$
$\mathrm{X} 2+0,467 \mathrm{X} 3$

Konstanta sebesar 9,364, koefisien Xl(Pola Asuh Otoritatif) sebesar 0,252, koefisien X2 (Kontrol Diri ) sebesar-0,235, dan koefisien X3 (Ketrampilan Komunikasi) sebesar 0,467 Persamaan regresi tersebut berarti bahwa antara Pola Asuh Otoritatif, Kontrol Diri,dan Keterampilan Komunikasi secara bersama-sama berpengaruh terhadap Agresivitas. Adanya peningkatan Xl (Pola Asuh Otoritatif), X2 Kontrol Diri), dan X3 (Keterampilan Komunikasi), maka akan diikuti oleh rendahnya Agresivitas

Untuk mengetahui variabel Independent mana yang 
memberikan kontibusi terbesar terhadap variabel Dependent dilakukan dengan mengetahui kontribusi masing-masing variabel Independent terhadap variable dependent. Kontribusi masingmasing variabel diketahui dari koefisien determinasi regresi sederhana terhadap variabel terikat atau diketahui dari kuadrat korelasi sederhana variabel bebas dan terikat. Kontribusi didapatkan dengan melakukan pengkuadratan nilai $r$ karena ada nilai $r$ yang minus sehingga didapatkan sumbangan yang kongkrit

Tabel 18 Kontribusi Variabel

\begin{tabular}{|l|c|c|r|}
\hline \multicolumn{1}{|c|}{ Variabel } & $\mathrm{r}$ & $\mathrm{r} 2$ & \multicolumn{1}{|c|}{ Kontribusi (\%) } \\
\hline Pola Asuh (X1) & 0.318 & 0.1011 & $10.11 . \%$ \\
\hline Kontrol Diri(X2) & -0.198 & 0.0392 & $3.92 \%$ \\
\hline Ketrampilan Komunikasi (X3) & 0.380 & 0.1444 & $14.44 \%$ \\
\hline
\end{tabular}


Dan tabel di atas diketahui bahwa variabel yang memberikan kontribusi terbesar adalah variabel Ketrampilan Komunikasi (X3) yaitu sebesar 13,44\%, kemudian Pola Asuh (X1) dengan kontribusi $10,11 \%$ dan variabel Kontrol Diri ( X2 ) memilki kontribusi 3,92\%.

Hasil analisis pertama memperoleh nilai $\mathrm{F}=7,211, \mathrm{p}=0,000$ $(\mathrm{p}<0,05)$, dan $\mathrm{R} 2=0,213$. Hal ini menunjukkan bahwa terdapat korelasi antara pola asuh otoritatif (X1), kontrol diri (X2), dan ketrampilan komunikasi (X3) secara bersama-sama terhadap agresivitas (Y). Hipotesis yang pertama yang berbunyi "ada peran negatif antara pola asuh otoritatif, kontrol diri, dan ketrampilan komunikasi terhadap agresivitas " diterima.

Prosentase sumbangan pengaruh variabel independen pola asuh otoritatif (X1), kontrol diri (X2), dan ketrampilan komuniksi (X3) terhadap variabel dependen agresivitas (Y) sebesar 21\%. Pola asuh otoritatif, kontrol diri, dan ketrampilan komunikasi mampu menjelaskan sebesar $21 \%$ terhadap agresivitas. Sedangkan sisanya sebesar $79 \%$ dijelaskan oleh variabel lain yang tidak diteliti. Model persamaan regresi linier berganda yang diperoleh adalah:

$$
\mathrm{Y}=9,364+0,252 \mathrm{X} 1+-0,235
$$

$\mathrm{X} 2+0,467 \mathrm{X} 3$

Konstanta sebesar 9,364, koefisien X1 (Pola Asuh) sebesar 0,252 koefisien X2 (Kontrol) sebesar -0,235 dan koefisien X3 (Ketrampilan Komunikasi) sebesar 0,467. Persamaan regresi tersebut Pola Asuh Otoritatif, Kontrol Difi, dan Ketrampilan Komunikasi secara bersama-sama berpengaruh terhadap Agresivitas. Adanya peningkatan X1 (Pola Asuh), X2 (Kontrol Difi), dan X3 (Ketrampilan Komunikasi), maka akan menekan peningkatan Agresivitas.
Perilaku agresif dipengaruhi oleh banyak hal termasuk di dalamnya pola asuh orangtua, Pola asuh memberikan proses pembentukan kognisi individu yang hidup dalam lingkungan tersebut (Rahayuningsih, 2012) seorang remaja akan belajar dari lingkungan tempat tumbuh kembangnya sebagai sumber belajar untuk bersikap, remaja yang tumbuh dan berkembang dalam lingkungan penuh pengertian maka anak juga akan menjadi pribadi yang memiliki toleransi terhadap orang di sekitarnya, demikian juga sembaliknya bila dibesarkan dengan penuh ancaman dan kekerasan maka remaja akan akan belajar untuk bertengkar dan berkelahi.

Pola asuh otoritatif memberikan suasana yang hangat dan pengertian sesuai dengan kemampuan anak sehingga terjalin suasana hubungan sosial yang nyaman, Orangtua membuat tuntutan yang sesuai engan batas wajar disisi yang lain menunjukan kehangatan dan kasih sayang, mendengarkan keluhan dengan sabar dan anak diberi kesempatan untuk ikut dalam membuat keputusan (Baumrind dalam Berk, 2000).

Pola asuh otoritatif memberikan sumbangan untuk menekan tingkat agresivitas remaja karena remaja belajar dari lingkungan yang diciptakan oleh orangtua yang memberikan pengertian dan kemampuan untuk membangun toleransi dengan lingkungan di sekitarnya hal ini juga di telah dibuktikan dalam penelitian ini pada pengujian kedua hipotesis yaitu Uji terhadap variabel pola asuh otoritatif (X1) didapatkan 2, 379 dengan signifikansi $\mathrm{t}$ hitung sebesar 0.020 Karena $\mathrm{t}$ Intung lebih besar $\mathrm{t}$ Label $(2,379>2.007)$ atau signifikansi $t<$ dari $5 \%(0,020<0,05)$, maka Secara parsial pola Asuh (X1) berpengaruh 
secara signifikan terhadap agresivitas (Y).

Penelitian ini sejalan dengan penelitian yang dilakukan oleh Rahayuningsih (2012) yang menemukan bahwa pola asuh orangtua yang memberikan perlakuan dan komunikasi yang baik, maka terbentunya perilaku agresi fisik / verbal pada anak yang rendah.

Rodin (Widiana dkk, 2004) mengungkapkan bahwa kontrol diri adalah perasaan seseorang dapat membuat keputusan dan mengambil tindakan yang efektif untuk menghasilkan akibat yang diinginkan dan menghindari akibat yang tidak diinginkan, perilaku agresif sebagai tindakan merusak atau menyakiiti oranglain adalah sebagai tindakan yang merugikan oranglain dan tindakan yang tidak terkontrol. Individu yang mampu mengambil tindakan yang efektif tentu tidak akan melakukan perilaku agresif.

Berdasarkan teori tersebut maka kontrol diri berpengaruh terhadap agresivitas remaja. Kemampuan untuk melakukan kontrol diri yang baik akan menekan perilaku agresif sebagaimana dalam uji parsial variabel kontrol diri dengan taraf signifikansi 0,043 . Karena $\mathrm{t}$ signifikansi $\mathrm{t}<$ dari $5 \%$ $(0,043<0,05)$, maka kontrol diri berpengaruh terhadap agresivitas secara signifikan.Hal senada juga terjadi pada penelitian yang dilakukan oleh Prasetya (2010) yang menunjukkan Hubungan antara Kontrol diri dengan agresivitas supporter sepakbola dengan Hasil uji ada hubungan negatif yang sangat signifikan antara kontrol diri dengan agresivitas pada remaja putri $(\mathrm{r}=0,598$ dengan $p=0.000$. Semakin tinggi kontrol diri maka semakin rendah agresivitas pada remaja putri, begitu juga sebaliknya semakin rendah kontrol diri maka semakin tinggi agresivitas pada remaja putri.
Santrock (2007) menyatakan bahwa ketrampilan komunikasi adalah ketrampilan yang diperlukan dalam berbicara, mendengar, mengatasi hambatan komunikasi verbal, memahami komunikasi non verbal dan mampu memecahkan konflik secara konstruktif. Ketika seorang individu memiliki kemampuan untuk memecahkan konflik maka tidak akan terjadi perilaku agresivitas kepada orang lain sehingga kemampuan untuk melakukan proses komunikasi yang baik dengan didasari oleh ketrampilan komunikasi akan menekan terjadinya perilaku agresif sesuai dengan hasil penelitian dengan melakukan uji terhadap variabel ketrampilan komunikasi (X3) didapatkan t hittmg sebesar 2,848 dengan signifikansi 0,006 . Karena $\mathrm{t}$ hitting lebih besar $\mathrm{t}$ table $(2,848>2,007)$ atau signifikansi t $<$ dari $5 \%(0,006<0,05)$, maka Ho ditolak dan Ha diterima. Secara parsial ketrampilan komunikasi (X3) berpegaruh secara signifikan terhadap $\operatorname{agresivitas}(\mathrm{Y})$.

Dari penjelasan yang ada dapat disimpulkan bahwa ketrampilan komunikasi memiliki pengaruh terhadap agresivitas sesuai dengan data statistic yang ada. Maka ketrampilan komunikasi juga memberikan sumbagan pada proses untuk menekan agresivitas penelitian yang menguatkan adalah penelitian yang dilakukan oleh fatmawati (2010) dengan hasilpenelitian menunjukkan bahwa terdapat pengaruh yang signifikan dari keterampilan komunikasi interpersonal dan komunikasi kelompok secara bersama-sama terhadap resolusi konflik, yang dibuktikan dengan nilai Fregresi $=51,446$, yang lebih besar dari nilai $\mathrm{F}$ tabel dalm signifikansi $5 \%$ yaitu sebesar 4,02. Nilai $F$ yang positif menunjukkan adanya hubungan yang bersifat positif. Untuk mengetahui kontribusi Variabel Independent yang 
paling dominan terhadap variabel Dependent,

Dari tabel sumbangan variabel di atas diketahui bahwa variabel yang memberikan kontribusi terbesar adalah variabel ketrampilan komunikasi (X3) yaitu sebesar 14,44\%, kemudian pola asuh (X1) dengan kontribusi $10,11 \%$ dan variabel Kontrol Diri (X2) memilki kontribusi 3,92\%.

Ketrampilan komunikasi memiliki sumbangan yang paling besar terhadap agresivitas. Menurut DeVito (1995) mengungkapkan beberapa hal lain yang berhubungan dengan kemampuan dalam menjalin komunikasi salah satunya adalah Interaction management, yaitu adanya aturan main dalam menjalin komunikasi interpersonal seperti gerakan mata, tubuh dan wajah, ekspres, vokal, serta mempertahankan kelancaran komunikasi. Hal ini menunjukkan bahwa interaksi komunikasi adalah sebagai bagian dari kontrol perilaku yang nampak langsung dari seorang individu yang dapat langsung dilihat oleh individu yang lain sehingga orang yang mampu berkomunikasi dengan baik tentunya mampu mengontrol perilaku minimal dalam berkomunikasi dan menggunakan pemilihan kata dan bahasa non verbal yang baik. Remaja yang memiliki ketrampilan komunikasi yang baik tentunya akan mampu mengontrol perilaku dan kognitifnya dalam menyampaikan pesan yang yang akan disampaikan kepada orang lain.

\section{Kesimpulan}

Penelitian ini bertujuan untuk mengetahui hubungan pola asuh otoriatif, kontrol difi, ketrampilan komunikasi dengan agresivitas secara terpisah. Metode pengumpulan data dalam penelitian ini adalah dengan menggunakan skala Agresivitas, skala Pola asuh Otoritatif, skala Kontrol difi, dan Skala Ketrampilan Komunikasi yang disusun sendiri. Model skala yang digunakan adalah skala Liken. Dalam penelitian ini populasinya adalah siswa SMA kelas $\mathrm{X}$, yang berjumlah 7 kelas dengan jumlah keseluruhan 229 siswa dengan rumus slovien Pengambilan sampel dalam penelitian ini berjumlah 70 siswa dari 229 siswa yang ada, sehingga diharapkan sampel yang ditetapkan sudah representatif. Hasil penelitian menyebutkan variabel yang memberikan kontribusi terbesar adalah variabel Ketrampilan Komunikasi (X3) yaitu sebesar 13,44\%, kemudian Pola Asuh (X1) dengan kontribusi $10,11 \%$ dan variabel Kontrol Din ( X2) memilki kontribusi $3,92 \%$. Hasil analisis pertama memperoleh nilai $\mathrm{F}=7,211, \mathrm{p}=0,000(\mathrm{p}<0,05)$, dan $\mathrm{R}^{2}=0,213$. Hal ini menunjukkan bahwa terdapat korelasi antara pola asuh otoritatif (X1), kontrol diri (X2), dan ketrampilan komunikasi (X3) secara bersama-sama terhadap agresivitas (Y).

\section{Referensi}

Albert D. (2012). Patterns of Adolescents' Beliefs About Fighting and Their Relation to Behavior and Risk Factors for Aggression.J Abnorm Child Psychol. 40:787-802.

Andayani, B\& Koentjoro (2004) Psikologi keluarga anayah menuju coparenting. Jakarta: PT. Delta Persada.

Andrew M. (2010). Patterns of Physical and Relational Aggression in a School-Based Sample of Boys and Girls J Abnorm Child Psychol 38:433-445.

Arikunto, S. (2010). Menejemen Penelitian. Jakarta: Renika Cipta.

Azwar, S. (2010). Penyusunan Skala Psikologi. Yogyakarta: Pustaka Pelajar.

Azwar, S. (2012). Validitas dan Reliabilitas. Yogyakarta: Pustaka Pelajar. 
Bandura, A. (2004) Sosial Learning Theory. EnglewoodClifs, New Jersey: Prentice-Hall, Inc.

Baron, RA., Byrne, D. (1984) Understanding human Interaktion fourth edition. Massachusets: Allyn and Bacon inc.

Baron,A., R \& Byrne, D. (2005). Psikologi Sosial Edisi 10. Jakarta: Erlangga.

Berkowitz, L. (2003). Emotional Behavior: Mengenali Perilaku dan Tindakan Kekerasan di Lingkungan Sekitar Kita dan Cara Penanggulangannya. Buku Kesatu. AlihBahasa : Hartatni Woro Susiatni. Jakarta: PPM.

Brigham. (1991). Sosial Psychologi. Second edition. Canada: John Willey and son

Dariyo A (2004) Psikologi perkembangan remaja. Bogor Selatan: Ghalia Indonesia.

De vito (1995). The Interpersonal Communication Book. (7th Edition). New York :Harper Collins College Publisher. Flippo, E.B.

Dinar, Wiwin (2006).Ketrampilan anak pra sekolah ditinjau dari interaksi guru-siswa Model mediated learning Experience. Jurnal penelitian Humaniora No 9 Hal 67-69: Universitas Muhammadiyah Surakarta.

Edy, Irawan. (2013). Efektivitas Teknik Bimbingan Kelompok untuk Meningkatkan Konsep Diri Remaja. PSIKOPEDAGOGIA Jurnal Bimbingan dan Konseling, Vol.2 (1): 32-46.

Fatmawati A (2010) Komunikasi Interpersonal, Komunikasi Kelompok Resoles Ikonflik. Skripsi tidak diterbitkan. Surakarta: Universitas Muhammadiyah Surakarta.

Gunarsa .S.D (2004). Dari anak sampa iusia lanjut: Bungarampai
Psikologi perkembangan. Jakarta: PT BPK Gunung Mulia.

Hanif. (2005). Perbedaan Tingkat Agresivitas SMU Muhammadiyah 1 Yogyakarta berdasarkan pola asuh dan jenis pekerjaan orangtua. Humaniora, Vol. 6, No. 2, 2005: 144154.

Hertinjung, Sri. Wisnu. Partini. Pranisti,

Hurlock E.B. (2002) Perkembangan anak jilid 1 Jakarta: PT Gelora Aksara Pratama.

Judith. R (2001). Agresion in toddler: Association with parenting and marital relation. Journal of genetic psychologyvol 162 No 2 hal 228241

Liliweri A (1997). Komunikasi antar Pribadi. Bandung: CitraAditia.

Myers.D.G (2012). Psikologi Sosial. Buku kedua. Alih Bahasa: Aliya Tusyani dkk. Jakarta: Salemba humanika.

Prasetya, A (2010) Hubungan antara Kontro ldiri dengan agresivitas supporter sepak bola. Skripsi (tidak diterbitkan) Yogyakarta: Universitas Islam Indonesia.

Priyatno, D. (2010). Paham Analisa Statistik Data Dengan SPSS. Yogyakarta : Media Kom.

Rakhmat.J. (1992) Psikologi komunikasi. Bandung: Rosdakarya.

Santrock J.W. (1998) adolescence by the McGraw-Hill: Companies Inc.

Santrock J.W. (200) Perkembanga anak Jakarta: Erlangga.

Santrock J.W. (2007) Remaja Edisil 1 Jilid 1 Jakarta: Erlangga.

Sarafino, E.P. (1990). Health Psycology: Biopsycososial interaction, Singapore: John Willey $\&$ Son.

Sari D.p. (2008) Pola asuh orang tua dalam mengembang kan perilaku anak. Fokus Volume VIII No 2: 127130. 
Sarwono. (1992) .Teori Psikologi Sosial. Jakarta : Raja Grafindo Persada.

Sugiyono. 2008. Metode Penelitian Pendidikan (Pendekatan Kuantitatif, kualitatif, dan $R \& D$ ). Bandung: Alfabeta.

Suryabrata,S. (2005) Pengembangan alat ukur Psikologis. Yogyakarta: Andi offset.

Widiana, H. Herawati S., \& Hidayat R. (2004) Kontrol diri dan kecenderungan kencanduan internet. Humanitas: Indonesia Psycological journal Vol IX No:6 hal 57-63.

Widyaningrum. (1998).

Kecenderungan agresif remaja ditinjau dari persepsi penerimaan orang tua dan solidaritas teman sebaya. Skripsi. (Tidak diterbitkan) Semarang: Universitas Katholik Soegi jopranoto.

Wungu. (1998). Kecenderungan agresif remaja tuna rungu ditinjau dari segi ukuran keluarga. Skripsi. (Tidak diterbitkan) Semarang: Universitas Katholik Soegij opranoto .

Yeni M (2011) Bermain role playing untuk meningkatkan ketrampilan komunikasi siswa TK. Skripisi (Tidak Diterbitkan) Yogyakarta. Universitas Ahmad Dahlan.

Yusuf.S. (2000). Psikologi perkembangan anak dan remaja. Bandung: Remaja Rosdakarya. 